\title{
Establishing the Intimate Link: 20th Century Tropical Agriculture and the Establishment of the Coconut Zone
}

\author{
Philip Jan Cerepak \\ Department of History, University of Wisconsin Madison, United States
}

DOI: https://doi.org/10.14710/jmsni.v4i1.8026

\begin{abstract}
This paper examines the role of colonial science institutions in imagining and developing the Coconut Zone, an area of intense coconut production that extends from the small Pacific island chains encompassing the Caroline and Marshall Islands, all the way to northern Papua, the Philippines, Indonesia, Malaysia, Sri Lanka, and Southern India. Through an examination of European colonial science institutions, as well as the Philippine Bureau of Science, and Agriculture, this paper establishes the intimate connection between western consumers and tropical producers. Here, within the agricultural institutions, we are able to see the burgeoning demand for

Received:

June 8, 2020

Revised:

June 10, 2020

Accepted:

June 15, 2020

${ }^{*}$ Corresponding Author:

erepak@wisc.edu

copra production and a formation of a distinct Coconut Zone. This paper builds upon Sydney Mintz's theoretical articulation of sugar production to situate copra, the dried meat of the coconut, in conversation with other global, colonial commodities.
\end{abstract}

Keywords: Coconut; Copra; Tropical Agriculture; Commodity; Colonial Science; Environment.

\section{Introduction}

In 1938, Charles Howard Edmondson, a marine biologist at the University of Hawaii-Manoa, conducted a coconut dispersal experiment by testing the hypothesis that coconuts could germinate after extended exposure to ocean water. Published in 1941, titled, "Viability of Coconut Seeds After Floating in Sea", Edmondson placed coconuts, grown in the Central Pacific island of Oahu, Hawaii, in three different ocean locations-Pearl Harbor, Kaneohe Bay, and Waikiki reef. After floating the fibrous drupes for a range of 22-116 days, Edmondson placed the coconuts in different soil conditions and recorded the germination time. Overall, Edmondson concluded that coconut seeds were capable of germinating regardless of sea exposure. Though the husk absorbed ocean water, he noted observable signs of germination while in the process of floating and continued germination while on land. Edmondson's study, though not wholly identical to the broad spectrum of ocean conditions, provided valuable evidence that coconuts could indeed float and populate distant islands potentially untouched by humans (Edmondson, 1941). To an outside observer, Edmondson's study appears, at first blush, more of a novelty than actual science. However, like most scholars, his floating coconut experiment was in direct conversation to a much larger scientific debate - where did the coconut originate and how was it disseminated?

As early as 1879, Western naturalists and botanical scientists proposed different theories into the coconut's origin and its dispersal. Given the peripatetic palms' presence on distant tropical islands, many people believed it originated in Asia and was distributed during prehistoric times by ocean waters. At the turn of the 19th century, Orator F. Cook, an American botanist, published, "The Origin and Distribution of the Cocoa Palm" and made the debate surprisingly contentious. In the article, Cook made two arguments: first, coconuts originated on the American continent; and second, their distribution was the result of human agency and not maritime currents (Cook 1901, 257-291; Beccari 1917; Berry 1926; Cook 1910-1912; Hedley 1896; Hill 1929; Ridley 1930).

Cook's theory on the coconut's origin was immediately called into question by Odoardo Beccari, an Italian naturalist whose name is linked to the baccariophoenix, a species of Madagascar 
palms closely related to the coconut genus. Beccari's 1917 article, "The Origin and Dispersal of Cocos Nucifera", was published in the Philippine Journal of Science and re-affirmed the coconut's Asiatic/Malay origin, stating that not all palms originated in the Americas, as Cook hypothesized. Additionally, Beccari argued that coconuts did not need humans for its dispersal, citing the 1883 eruption of Krakatoa in the Sunda Strait and the repopulation of coconuts on the island as direct evidence.

Coconut debates have continued unabated to the present, providing a more cogent, though complex, rendering of the coconut's origin and dispersal (Harries 1978; Harries 1981). DNA evidence suggests two independent origins of cultivated coconuts in southern India as well as maritime Southeast Asia. Additionally, these debates weave together historical evidence of the dispersal of coconuts in three general phases. First, Pre-Colombian Austronesian seafarers, more than likely from the Philippines, brought the coconut eastward to Polynesia and the Pacific coasts of Latin America. Next, coconuts spread westward in the Indian Ocean as a result of Austronesian expansion to Madagascar. Finally, European trade in India and Southeast Asia beginning in the early $17^{\text {th }}$ century, introduced coconuts to the Atlantic Coasts of Africa and South America, as well as the Caribbean (Gunn 2011).

When one examines the long record of coconut research, O.F. Cook's theory seems like a momentary blip or a standard deviation likely to occur in any academic field. Cook's disinterest, however, in what he calls "the botanical romance" with the fallen coconut gone adrift, populating islands, coincided with his belief that human beings had a much greater impact on the spread of coconuts than nature. It is safe to argue that humans have played an important, if not, dominant role in the distribution of coconuts worldwide.

While there have been scientific compendia dedicated to coconut cultivation, and while coconuts can be seen along the entire equator, occupying large swaths of land in coastal nations, very little work has been done to further our collective understanding of the relationship of coconut plants and the complex societies that use them. Historians often employ commodities as a unique lens to view the political and social developments across disparate global regions, unfortunately for coconuts they remain seemingly invisible within this otherwise burgeoning literature. The historical research into coconut cultivation is better compared to the consumption of tropical durian fruit commonplace in its home region, but ignored in the world beyond.

In one sense, the invisibility of coconuts is connected to the spectacular violence associated with other colonial commodities. For instance, sugar production is highly recognizable. Beginning in the 16th century, the Spanish and Portuguese wave of genocidal violence fostered sugar plantations that replaced indigenous populations. Both Spanish and Portuguese ships carried African slaves to South America and the Caribbean, beginning the long history of the Atlantic slave trade and planation sugar production. For the next three centuries the Atlantic Ocean was the center of a triangular trade network fueled by African slaves brought to the Americas to produce sugar, cotton, and tobacco for export to Europe. Manufactured goods, in turn, were produced on the European continent and the profits were used to purchase more slave labor to sustain the highly volatile, repressive plantation economy.

Additionally, at the turn of the 20th century, the rubber booms were linked to the murderous globalization process that indiscriminately killed the Amerindians of Brazil. On the African continent, in the Congo Free State, better known as King Leopold's "heart of darkness," his colonial militia, the Force Publique, carried out unspeakable atrocities to increase colonial profits through rubber extraction that contributed to the deaths of ten million Africans. Other commodities had unfortunate histories, notably the displacement of Native Hawaiians on Dole pineapple plantations and economic exploitation by the United Fruit Company in Central America's "Banana Republics". It is no wonder then, if violence and repressive economic systems are the defining features of colonial commodities, that coconut production is largely ignored. Nonetheless, anthropologist Douglas L. Oliver has argued that the coconut is a dominant economic force in recent Oceanic history, more than any other factor (Oliver 1988).

Douglas Oliver's assertion is primarily directed toward the production of copra, the dried meat of the coconut. This distinction, while seemingly small, has a profound impact on how we view coconuts - either as subsistence crop, or a useful colonial commodity, supplying industrial nations 
with a cheap, high-caloric, and highly adaptable vegetable oil for the production of margarine, bath soaps, and industrially processed foods. Unlike sugar that has industrial infrastructure for both farmgate processing and consumer packaging, coconuts have a marked disparity of almost crude onfarm husking of the meat with an iron spike and its drying on a bamboo mat, married, paradoxically, with the very sophisticated industrial chemistry to extract marketable consumer commodities. Within this paradox lies the complex politics whose subtleties of exploitation and social conflict have eluded historians who focused on the bloody tragic histories of colonial commodities such as sugar and rubber. This intimate connection, between western consumers and tropical producers, has also created a linked chain of copra production that extends from the Pacific Ocean, encompassing the Caroline and Marshall Islands, all the way to northern Papua, the Philippines, Indonesia, Malaysia, Sri Lanka, and Southern India -- forming what I call the Coconut Zone.

Within this zone, we find an intimate connection between western consumers at one end of the commodity chain, to tropical coconut producers on the other. As Sydney Mintz argued in, Sweetness and Power: The Place of Sugar in Modern History, production and consumption of commodities are closely bound together. He explained that the intensification of consumption, places those in power of the commodity with the responsibility for the presence of new products, altering the products meaning (Mintz 1985, 153). Fundamental in the process of changing the meaning of a commodity are colonial sciences and plantation agricultural systems. European traders and agriculturalists viewed the plantation as the most efficient method to produce large quantities of valuable agricultural goods. Plantations in this sense symbolize the intense consumption of a single agricultural good reinforcing the importance of the consumer, the final stage in the commodity chain.

In the case of sugar, cotton, and tea, three of the earliest and more valuable agricultural products during the early modern period and modern period, the process of commodification and the process of meaning are entangled within the web of production and consumption. For nonEuropean societies, sugar was not the white crystal staple in the home kitchens, but instead, a stalk chewed or pulverized for its sweet liquid. The act of refining raw sugar into white sugar was a process that not only changed its chemical structure, but changed the meaning of the product, reinforcing methods of extraction and commodification.

Like all commodities, coconut production has an intrinsic characteristic that can influence the society in which it inhabits. In the case of Cuban Counterpoint: Tobacco and Sugar, Juan Ortiz argues that cultivation of these two commodities, one indigenous and one foreign, are two sides of a coin, tobacco on the one hand is passive and sugar is active. The two commodities impacted each society differently based on the required labor and processing needs (Ortiz, 2001). Coconut cultivation did not undergo the same process of commodification as other commodities such as sugar, tobacco, and bananas, thus laying outside the peripheral analytic gaze. For coconuts, the paradoxical pairing of crude farmgate processing at the production level with sophisticated industrial chemistry lends the commodity trade its distinctly global character and defines the Coconut Zone.

Furthermore, the Coconut Zone is more than an imagined space, it is an integral economic sphere supplying Western markets with a necessary vegetable oil. As noted in the 1948 Economic Botony publication, "The Coconut Palm: Mankind's Greatest Provider in the Tropics", written by Oscar K. Moore, the principal commercial production of copra occurs within the stated Coconut Zone (Moore, 1948). Thus, the conceptual framework of the Coconut Zone builds the foundation for comparative studies within regions of Asia and the Pacific as well as Western consuming nations.

This article, though unable to address the breadth of analysis in which this topic deserves, will examine a small, but fundamental development during the 20th century within the Coconut Zone tropical agricultural institutions. Here, within the agricultural institutions, we are able to see the burgeoning demand for copra production and a formation of a distinct Coconut Zone. Additionally, this article focuses on the production of scientific studies during the late $19^{\text {th }}$ and early $20^{\text {th }}$ century in

\footnotetext{
${ }^{1}$ The meaning of coconuts, copra, and coconut oil has not been a unilateral transformation of meaning, steaming from metropolitan consumers to peripheral producers. Instead, coconut and copra producers throughout the coconut zone resisted western attempts to control the meaning of coconuts and coconut products. Concurrently, coconut cultivation: the act of planting; nurturing; and harvesting; was resistant to western-style agricultural production, though impacted nonetheless. This essay will not address the resistant characteristics embedded within coconut production, as it is beyond the scope.
} 
order to show the connection between the colonial sciences and the colonial economy. This work draws upon my archival research in the US National Archives as well as several locations in the Philippines examining the institutional evolution of the Philippine coconut industry and its colonial past.

\section{Tropical Sciences and The Coconut Zone}

During the $18^{\text {th }}$ and $19^{\text {th }}$ century, colonial regimes utilized the natural sciences and the collection of botanical material to make sense of newly encountered environments. As cartography expanded the colonial vision and imperial worldview, the natural sciences enveloped the flora, fauna, and peoples of the tropical world for exploitation by the industrializing Torrid Zone (Driver 2004; Felix \& Martins 2005; Raby 2017). Botanical expeditions were an important aspect of the colonial reach into these new territories making the unfamiliar familiar through the act of identifying and cataloguing the natural environment of the tropics (Bleichmar 2012, 45-50; Endersby 2008). In a sense, botanical expeditions imposed order on the natural environment through classification systems that in turn facilitated the commodification of the natural environment.

Groups such as The Linnaean Society of London, founded in 1788 after the Swedish naturalist Carl Linnaeus, sought to organize the natural environment into a taxonomic hierarchy, while other groups such as the Royal Botanic Society disseminated botanical knowledge and its application for commercial uses. Science in the colonies was a tool of control for the benefit of metropole commerce (Hodge 2011, 3-29; Foucault 1971). The European colonial regimes' acquisition of botanical material for commercial exploitation, when applied to coconuts, created a coconut zone of condensed cultivation.

At the turn of the $20^{\text {th }}$ century the coconut's spread was not concentrated in any specific area. In 1896, Polynesia, Java, Sumatra, Ceylon, and India comprised roughly 657,245 hectares of cultivated coconut land, while Central and South America represented roughly 516,000 hectares of total world production (Copeland 1908). These statistics exclude production in Africa however they indicate the vast geographical spread of coconuts and also the general lack of concentration within the modern day Coconut Zone. Coconuts were found on nearly every island and on the most distant coral atoll ecosystems (Hedley 1896-1900, 13).

After the establishment of the East India Company's trading base in Singapore in 1819, coconut planting began on the southeast coast of Malaya but did not extend much until after 1837 (Child $1971,144)$. Europeans primarily consumed and traded coconuts for candle production. However, William Marsden noted the varied uses of the nut and its importance to communities in his history of Sumatra. Marsden's observations show an increasing interest in coconut use by Europeans, but also the beginning of an island-centric understanding.

The coconut-tree, Kalapa, noir (cocos nucifera), may be esteemed the next important object of cultivation from the uses to which its produce is applied; although by the natives of Sumatra it is not converted to such a variety of purposes as in the Maldives and those countries where nature has been less bountiful in other gifts. Its value consists principally in the kernel of the nut, the consumption of which is very great, being an essential ingredient in the generality of their dishes. From this also, but in a state of more maturity, is procured the oil in common use near the sea-coast, both for anointing the hair, in cookery, and for burning lamps... (Marsden 1917, 82).

The development and concentration of copra within the Coconut Zone can largely be attributed, though not fully, to early European misconceptions around coconut cultivation and its relationship to islands. As noted within the introduction, many 19th century scientists romanticized the origins and dispersal of the coconut throughout an island world. Botanical explorations were fascinated with the nut and its relationship to local populations in the Pacific and Indian Ocean, despite the coconut's existence in parts of Africa and the Americas. Many coconut studies introduced ideas that ocean and saltwater were important factors in cultivation. European agriculturalists in particular, viewed sandy soils as a necessity for the growth of coconut trees. In 1836, when coconut oil was first used in the manufacture of European candles, British scientists began the process of 
defining zones particularly suitable for coconut cultivation. James Low, an officer turned captain in the English East India Company, who spent much of his career in Penang and later Singapore before retiring in 1850, published his dissertation outlining the potentials of tropical crop cultivation stating that the coconut "is partial to a sandy soil in the vicinity of the sea" and that access to greater amounts of beach territory would provide an abundant source of coconuts as opposed to inland soils (Low 1836: 43).

The use of oil from the dried meat of the nut was a relatively new industrial process and was established in the 1880s. Before copra became an important commodity for European trade, coconut cultivation was a subsistence crop wherever the tree was grown. However, with the introduction of copra, European and Western interest grew, particularly with the commercialization of this crop.

In 1912, Sir William H. Lever, a store clerk turned manufacturer and founder of Lever Brothers wrote, "I know of no field of Tropical Agriculture that is so promising at the present moment as coconut planting, and I do not think in the whole world there is a promise of so lucrative an investment of time and money as in this industry" (Smith 1911, xxi). Published against the backdrop of declining prices in the Brazilian rubber trade, Coconuts; The Consols of the East, promised readers in Europe guaranteed financial returns. If rubber symbolized a volatile commodity to be sold in the stock market, coconuts symbolized a strategic and calculated investment, similar to a government issued bond (Cronon 1991, 28-31). Land, as argued by the authors, could be transformed into an equity, as long as planters were able and willing to withstand the seven year wait for trees to mature and fruit abound.

The discussion of coconuts in Conols of the East and the general epistemology of tropical agriculture was similar to American colonial concepts of timber which transformed trees into commodities and North American forests into sites of resource extraction whereby wealth could be extracted through a process of transforming natural capital into liquid capital, rendering the natural environment a source for material wealth. In the writings of $\mathrm{H}$. Hamel Smith and F. Pape they compare coconuts to a consol, short for consolidated annuity, or a perpetuated bond issued by the government with no maturity date, encouraging the idea of transforming natural environments into sites of coconut cultivation, later to be rendered as equity within the eyes of the planter. The concept of a bond also required a sense of faith between purchaser and issuer, that the coupon disbursed could be redeemed at a later date for monetary value. In this case, the authors and Lever were arguing that coconuts could be transformed into a commodity of value in the world market.

The explosion of coconut cultivation was a result of the commodification of the coconut meat into copra for industrial use by European countries. The excitement of this new tropical industrial product can be seen in two important publications of the time that stated:

"This volume, in a word, has been arranged so as to mainly deal in plain language with the practical side of the Coconut industry and to emphasize, in the first place, all information which should lead to an interest being taken in, and to the adoption of, an Industry which has played, and is destined to play in the near future, an important part in the successful development of some of our most promising Tropical Dependencies and Colonies (Smith \& Pape 1911, XI).”

"The points enumerated in this article, together with the fact that the world's production of edible animal fats is not growing in proportion to the increase in civilization and consequent higher state of living, are the causes, among others referred to later, for the awakened interest in the copra or coconut industry, and the feverish anxiety which is displayed to control plantations of the Coco-nut tree (Curtis Gardner 1912, 4)."

Nowhere else was the popularization and potential profitability more visible than in the Philippines, a newly acquired colony by the United States in 1898. One of the first acts by the Philippine Bureau of Insular Affairs, was act No. 261 organizing the Bureau of Agriculture which provided a chief of the Bureau, as well as, experts in animal industry, botany, agronomy, tropical agriculture, plant culture, and breeding. Passed on 30 April 1902, the act identified the Bureau's fundamental tasks which included, the investigation, understanding, and dissemination of cultivation and agricultural techniques for the improvement and introduction of valuable products (Report of the Philippine Commission 1902; Report of the Chief of the Insular Bureau of Agriculture for the Year Ending August 30, 1902). 
The Insular Bureau of Agriculture replicated other colonial institutions and began cataloguing the islands for the profitable development of agricultural goods. As stated by the Bureau's botanist, "A thorough and scientific knowledge of the plants of the islands is the basis on which we must build our future economic work on timber, fiber plants, fruits, medicinal plants, food plants, and those that produce dyes, tans, gums, resins, gutta-percha, etc" (Report of the Philippine Commission 1902; Report of the Chief of the Insular Bureau of Agriculture for the Year Ending August 30, 1902). Because American officials viewed the Philippine islands like other European colonies in the region, the Bureau looked to their institutions for a model to replicate as noted in the 1902 Philippine Commission Report:

In the colonial possessions of England and Holland the fact that an accurate knowledge of the flora of the country is the first essential for future successful agricultural and forestry work, was realized in the beginning and, consequently, we find in Java, Hongkong, Singapore, Penang, Ceylon and India long established botanical gardens, each with magnificent collections of growing plants, both native and foreign, large herbaria and complete botanical libraries. In all these institutions the primary object has been to study and classify the flora of the several colonies and, secondly, to inquire into the economic agricultural forestry problems. The primary work has been accomplished and now these institutions, thus thoroughly grounded, are working largely on economic questions pertaining to agricultural and timber industries (Report of the Philippine Commission 1902; Report of the Chief of the Insular Bureau of Agriculture for the Year Ending August 30, 1902)."

For the United States, the main crops of interest in the first 5 years of colonization were sugar, hemp, tobacco, and abaca. Much of the documentary evidence and reports of the Philippine Commission reveal that during the Bureau's assessment of the islands, sugar was to be the primary crop, so much so, that the commission instructed the new President of the agricultural school to link it to prominent sugar areas. The appointed president of the proposed school of agriculture, George D. Bill, was directed by the Philippine Commission to assess land in the Philippines. One of his first observations was on the island of Negros where he noted the physical description of the island and properties of the soil. Much of the islands were suitable for cane sugar as that was the primary interest of the investigation, detailing that from the eastern portion of the island, the land was considered to be some of the most profitable on the island and that the soil was abundant in nutrients. During his observations in Negros, George Bill also noted coconut groves along both coasts of the island stating that the majority of production was not dedicated to copra. Instead, the owners of the coconut tree produced coconut alcohol from the flower stems. Additionally, the majority of coconuts were used for local oil consumption (Manuscript Reports of the Second Report of the United States Philippine Commission on Affairs in the Philippine Islands. Vol. 2. Entry 91).

The Philippine Bureau of Science can be directly connected to the advancement of an industrialized copra industry in the Philippines. During the transition period from Spanish to American rule, the Philippine coconut industry's most prominent zone was located in Tayabas (present day Quezon province). Though copra production existed, the region was more known for its production of tuba, an alcohol beverage derived from the fermentation of coconut water (Copeland $1908,126)$. The production of coconut wine was so popular and an integral part to the local Tayabas economy that the Philippine methods of wine making migrated to parts of Mexico during the Manila Galleon.

As stated above, the Philippine Commission envisioned the islands as a potential sugar producing colony. However, due largely to the beet sugar interests in the United States, investments in sugar land by American citizens were limited, allowing space for a Philippine copra industry, as evidenced by the explosive production of coconut experiments conducted by Philippine Bureau of Science. In 1906, the first publication year of the Philippine Journal of Science, three articles published by Paul Freer, the director of the Bureau of Science, Edwin Bingham Copeland, botanist and instructor at the newly established Agricultural University located in Los Banos Laguna, and agriculturist Herbert Spencer Walker, established the fundamental knowledge that coconuts could be cultivated anywhere, even away from the ocean. Copeland's piece in particular emphasized this point: 


\begin{abstract}
"As is true for every cultivated plant, it is possible to create for the coconut conditions altogether more favorable for its utmost thrift than are ever known to occur in nature. It naturally grows in a "poor" soil - that is in one in which its mineral and nitrogenous raw food is present in very dilute solution. We can improve its environment in this respect, and can profitably carry this improvement much further than is the general practice at present (Copeland 1906).”
\end{abstract}

The Philippine Journal of Science did much to disband the myth that oceans and salt water were important for coconut cultivation. The majority of production during the turn of the century, as mentioned earlier, occurred in coastal regions. Herbert S. Walker, chemists at the Bureau of science, in his publication "The coconut and Its relation to the Production of Coconut Oil" briefly made mention of this myth of the coastal propagation by stating that the trees that grow closer to the seashore are "noticed" to be more productive than those that grow further away from the shore (Walker, 53-54). After studying the different soil samples and different areas of coconut trees, Walker determined that, "the superior growth of trees near the sea might well be accounted for theoretically by the physical characteristics of the soil alone (Walker, 59)." From the 13 different soil samples he determined that chemically, soils further inland actually proved to be superior, leading to greater production of the coconut flesh for copra.

During the first 20 years of The Philippine Journal of Science, the institution published extensively on coconut research. From 1906 to 1926, the journal published twenty-six papers related to the coconut industry, with nine of those occurred within the first two years (Dayrit 2005, 1-10). Some of the major themes besides geographic location for optimal coconut growing investigated by the Bureau, were, the keeping qualities of copra and the causes of its rancidity. The investigations examined various methods of copra drying and optimal processes for oil extraction. From 1910 to 1926, the acreage and number of trees dedicated to the cultivation of copra nearly tripled from 406 thousand acres to 1,166 million, surpassing corn and sugarcane cultivation within the islands (Snodgrass 1928, 61).

Throughout the Coconut Zone, coconut cultivation grew rapidly, though still considered, in its infancy. Total value of Philippine copra exports in 1902 was 1,001,656 tons and by 1903, exports increased to 4,472,697 long tons (Fourth Annual Report of the Philippine Commission, Report of the Civil Governor for the Period Ending December 23, 1903). Southeast Asia, particularly, became a major site for increased coconut cultivation as noted in the statistics in Table 1 .

Table 1. Production of the Chief Copra Growing Island (in tons)

\begin{tabular}{llllll}
\hline Countries & 1905 & 1907 & 1909 & 1911 & 1912 \\
\hline Java & 107,709 & 68,000 & 72,000 & 99,700 & 89,048 \\
Strait Settlements & 58,915 & 58,914 & 74,192 & 97,254 & 81,709 \\
Philippine Islands & 52,520 & 50,694 & 77,699 & 118,323 & 174,033 \\
Tongan Islands & 7,582 & 7,360 & 14,834 & 12,721 & 11,120 \\
Madagascar & 25,961 & 17,290 & 19,154 & 39,979 & 37,642 \\
Sangar & 19,514 & --- & --- & --- & --- \\
Ceylon & 17,739 & 19,216 & 39,226 & 33,637 & 29,942 \\
Zanzibar & 2,514 & 7,158 & 7,873 & 11,319 & 9,332 \\
Mozambique & -- & 2,788 & 3,665 & 3,411 & 3,306 \\
Federated Malay States & ---- & --- & 6,268 & 8,103 & 7,771 \\
German New Guinea & & --- & 8,653 & 9,553 & 11,130 \\
\hline
\end{tabular}

Sources: Snodgrass 1928, 50-61.

From the point of view of political control, the Dutch and the British both had one third of the world's trade in coconuts, while the United States had roughly one fourth. From 1926 onward, the Dutch and the United States would maintain dominance in world trade with copra production concentrated particularly in the island of Sulawesi in Indonesia, while in the Philippines, copra production shifted southward to the underdeveloped, agriculturally rich land in Mindanao. One reason for the shift and increase in copra production in Indonesia was WWI and the increasing need for a cheap fat substitute in the European diet. Dutch East India expanded their export of copra from 
3,330,000 pounds in 1913 to 173 million pounds by 1920. In terms of world production, neither Sri Lanko nor the Straits of Malaya increased their percentage of total production, and Indian exports decreased to an insignificant amount of the total world production (Snodgrass 1928, 99). As a result, by 1924 the Dutch East Indies and the Philippine Islands accounted for nearly 62 percent of the world's total production of copra and coconut oil (Snodgrass 1928, 94). The island of Sulawesi would remain a major world producer of copra throughout the 1950s and early 1960s until the Philippines would take over the copra market almost entirely.

A brief examination of increased western copra consumption helps us understand the explosion of coconut production within the Coconut Zone. Starting with the year 1912, no coconut oil was used in the making of American margarine. By 1926, coconut oil comprised over 40 percent of the total fat used in margarine production and became the principal vegetable oil used in the United States (Snodgrass 1928, 8). With a consistency stiffer than lard and a lower burn temperature than butter, along with its relative sweetness, coconut oil became a versatile major raw material for specialty products such as confectionery, bakery goods, and popcorn. The oil's high lauric acid content of coconut oil contributed the coconut's adaptability in replicating similar properties in butterfat, and as a result was the principal ingredient in "butter" for movie theatre popcorn (Schwarts 1988). By 1950, coconuts became the main oil source in the world market. After U.S. imports dropped from 825 million pounds in 1947 to 554 million pounds in 1952, copra and coconut oil imports into the United States alone rose to 730 million pounds in 1963 and nearly 900 pounds by 1967 (Kromer 1964; Kromer 1968). These numbers represent over one-fourth of the total volume in world trade and marked the United States as the world's largest single importer of coconut oil and copra (Kromer 1964; Kromer 1968).

Along with being used for human consumption, European and North American markets used copra and its by-product, coconut oil, in the manufacture of soap. The same chemical property that gives copra its sweet flavor and its similar melting consistency of butter, lauric acid, created the lathering quality sought after by soap manufacturers. In 1912, only 10 percent of the soap manufactured in the United States used coconut oil. By 1923, the use of coconut oil more than doubled to roughly 23 percent (Snodgrass 1928, 10).

By 1947, the consumption of copra oil for soaps and detergents peaked at 511 million pounds, but then steadily decreased and from 1953 until 1958 was averaging roughly 170 million pounds. The decrease in volume of coconut oil in soap production is overall misleading, as the use of coconut oil for fatty acids steadily increased from 96 million pounds in 1947 to 274 million pounds by 1959 . One explanation for the decrease in coconut oil in soap production and an increase in oil for fatty acids is because of new cleaning consumer products that utilized the high-foaming, soluble properties of monoglyceride sulfates derived from coconut oil (Texter 2001, 10). As early as 1935, ColgatePalmolive Peet Co. introduced a soap free shampoo formulation under the brand name "Halo." In the 1950s and throughout the 1960s, Colgate manufactured on an industrial scale Arctic Syntex L and $\mathrm{M}$ and Monad G, utilizing coconut oil based monoglyceride sulfates, which were applied to household cleaners (Texter 2001, 10).

The global demand for copra, represented here by the United States shows the ubiquitous nature of copra as a versatile product for world consumption that met the many demands for food, cleanliness, and wartime needs. Copra would remain one of the largest consumed agricultural goods by the world market and an important commodity as the United States emerged from WWII as a major economic power, shaping further the production of copra in the Coconut Zone.

\section{Conclusion}

Today the coconut tree is an interwoven aspect of Philippine society. Out of the 81 provinces in the Philippines, 68 are coconut-producing regions. The tree itself is referred to nationally as, Ang puno ng buhay, or "the tree of life". Out of the 100 million people in the Philippines, it is reported that roughly 20 million people are dependent on the coconut industry for their livelihood, with farmers representing three million of that total. However, the complex industrial chemistry has made the study of copra production somewhat illusive for historical analysis, when compared to other colonial commodities. 
The impact of coconut production is not limited to the Philippines, but extends throughout the Coconut Zone - an area of intense copra production that extends from the small Pacific island chains, encompassing the Caroline and Marshall Islands, all the way to northern Papua, the Philippines, Indonesia, Malaysia, Sri Lanka, and Southern India. While there exists a small body of historical literature on coconut production, this paper establishes a unified zone directly connected to industrial colonial extraction of coconut oil from copra, the dried meat of the coconut. Additionally, this paper provides evidence of an intimate link between the increased consumption by western countries of coconut oil and the use of colonial sciences to connect tropical producers to western consumers.

\section{References}

Anonym. 1912. The Cult of the Coconut: A Popular Exposition of the Coconut and Oil Palm Industries. London: Curtis Gardner.

Anonym. Without year. "Industrial Surfactant Synthesis." In The Reaction and Synthesis in Surfactant Systems, edited by John Texter. United Kingdom: Taylor and Francis Group.

Beccari, O. 1917. "The Origin and Dispersal of Cocos Nucifera." Philippine Journal of Science, 12, C.

Berry, E. W. 1926. "Cocos and Phymatocaryon in the Pliocene of New Zealand." American Journal of Science 5 (12).

Bleichmar, Daniela. 2008. Botanical Expeditions and Visual Culture in the Hispanic Enlightenment. 45-50. Chicago: University of Chicago Press.

Child, R. 1971. Coconuts. London: Longman.

Cook, O. F. 1901. "The Origin and Distribution of the Cocoa Palm." The U.S. National Herbarium 7 (2): $257-291$.

Cook, O.F. 1910-1912. "History of the Coconut Palm in America." The U.S. National Herbarium 14.

Copeland, Edwin Bingham. 1906. "On the Water Relations of the Coconut Palm (Cocos Nucifera)."

Copeland, Edwin Bingham. 1908. Elements of Philippine Agriculture. New York: World Book Company.

Cronon, William. 1991. Nature's Metropolis: Chicago and the Great West. New York: Norton and Company.

Dayrit, Fabian. 1906. "A Brief History of the Philippine Coconut Industry as Reflected in the PJS, 1906 to 2005." The Philippine Journal of Science. Centennial Ed. Manila: Quezon City.

Driver, Felix. 2004. "Imagining the Tropics: Views and Visions of the Tropical World." Singapore Journal of Tropical Geography 25 (1): 1-17.

Edmondson, Charles Howard. 1941. "Viability of Coconut Seeds After Floating in Sea." Occasional Papers of Bernice P. Bishop Museum, 16 (December).

Endersby, Jim. 2008. Imperial Nature: Joseph Hooker and the Practices of Victorian Science. Chicago: University of Chicago Press.

Felix, and Luciana Martins, eds. 2005. Tropical Visions in an Age of Empire. Chicago: University of Chicago Press.

Foucault. 1971. The Order of Things. London: Longman.

Fourth Annual Report of the Philippine Commission, Report of the Civil Governor for the Period Ending December 23, 1903. Entry 91, BIA, RG 350, Box 5. USNA. B73.

Gunn, Bee F., Luc Baudouin, and Kenneth M. Olsen. 2011. "Independent Origins of Cultivated Coconut (Cocos nucifera L.) in the Old World Tropics." PLOS ONE, 6 (6).

Harries, H.C. 1978. "The Evolution, Dissemination and Classification of Cocos nucifera L." Botanical Review 44 (3): 265-319.

Harries, H.C. 1981. "Germination and Taxonomy of the Coconut." Annals of Botany 48 (6): 873 883.

Hedley, C. 1896. "A General Account of the Atoll of Funafuti." Australian Museum 3. 
Hedley, Charles. 1896-1900. The Atoll of Funafuti, Ellice Group: Its Zoology, Botany, and Ethnology, and General Structure Based on Collections Made By Mr. Charles Hedley, of the Australian Museum. Sydney: Sydney Museum.

Hill, A. W. 1929. "The Original Home and Mode of Dispersal of the Coconut." Nature 124.

Hodge, Joseph. 2011. "Science and Empire: An Overview of the Historical Scholarship." In Science and Empire: Knowledge and Networks of Science Across the British Empire, 1800 -1970. United Kingdom: Palgrave Macmillan.

Kromer, George W. 1964. Coconut Oil Imports and Consumption Increasing in the United States. Washington DC: Economic and Statistical Analysis Division, Economy and Research Service.

Kromer. W. 1968. The U.S. Oil Situation. U.S. Dept. of Agriculture.

Low, James. 1836. "A Dissertation on the Soil and Agriculture of the British Settlement of Penang or Prince of Wales Island." In The Straits of Malacca: Including Province Wellesley On the Malayan Peninsula with Brief Reference to the Settlements of Singapore and Malacca. Singapore: Singapore Press Free Press Office.

Manuscript Reports of the Second Report of the United States Philippine Commission on Affairs in the Philippine Islands. Vol. 2. Entry 91, BIA, RG 350. USNA. Box 922. 340.

Marsden, William. 1811. The History of Sumatra: An Account of the Government, Laws, Customs, and Manners of the Native Inhabitants. London: Thomas Payne and Son: London.

Mintz, Sidney. 1985. Sweetness and Power: The Place of Sugar in Modern History. 153. New York: Penguin Books.

Moore, Oscar K. (1948). "The Coconut Palm: Mankind's Greatest Provider in the Tropics." Economic Botany, 2, no. 2 (April-June): 119-144. https://www.jstor.org/stable/4251892

Oliver, Douglas L. 1988. The Pacific Islands (revised edition). Honolulu: University of Hawaii Press.

Ortiz, Juan. 2001. Cuban Counterpoint: Tobacco and Sugar. Duke University Press: Durham and London.

Raby, Megan. 2017. American Tropics: The Caribbean Roots of Biodiversity Science. North Carolina: North Carolina Press.

Report of the Chief of the Insular Bureau of Agriculture for the Year Ending August 30, 1902, in, Report of the Philippine Commission 1902. Part 3. Entry 91, BIA, RG 350, USNA. A1375A1380. 502.

Ridley, H. N. 1930. The Dispersal of Plants Throughout the World. L. Reeve and Co. Ashford: Kent.

Smith, H. Hamel, and F. Pape. 1911. Coco-nuts: The Consols of the East. London: Tropical Life Publishing Dep.

Snodgrass, Katherine. 1928. "Copra and Coconut Oil." Fats and Oils Studies, No. 2. California: Food and Research Institute, Stanford University.

The Copra Dock at Islais Creek 1947 - 1974. The ILWU Oral History Project. Vol. 2, part 1. Edited by Harvey Schwarts. From the Dispatcher, June 1998.

Walker, Herbert S. Without year. "The Coconut and Its Relation to the Production of Coconut Oil." The Philippine Journal of Science 1 (1): 53-54. 